\title{
https://doi.org/10.52240/1857-2367.2020.2(21).25 \\ REZERVAŢIA PEISAJERĂ „LA 33 DE VADURI”
}

\author{
Ştefan LAZU, Ludmila TALMACI, Alina PAVLIUC \\ Grădina Botanică Naţională (Institut) ,Al. Ciubotaru”, \\ Chişinău, Republica Moldova
}

\begin{abstract}
The landscape reserve "Thirty-three Fords", with an area of 244.7 ha, was evaluated floristically and phytocoenotically in the summer of 2011. The presence of Carpineto-Quercetum roboris forest with natural 70-100 year old stands was proved. Artificial black locust and coniferous forests occupy $38.7 \%$. In the valley of the Naslavcea River, the floodplain grassland vegetation persists, and on the slopes without forests - xeric grasslands. In the landscape reserve "Thirty-three Fords", 13 rare plant species mentioned in the Environmental Legislation of the Republic of Moldova (1996-1998) were identified.
\end{abstract}

Key words: Carpineto-Quercetum (roboris) forests, rare plants.

Rezervaţia peisajeră „La 33 de Vaduri” se află la sud de s. Naslavcea, raionul Ocniţa. Include parcelele 10, 11, 12, 13, 14 (fără subparcelele 13 L şi 14 E) din Ocolul Silvic Ocniţa, Întreprinderea pentru silvicultură Edineț. Suprafaţa rezervaţiei peisajere constituie 184 ha (conform Legii privind fondul ariilor naturale protejate de stat, 1998), iar conform amenajamentul silvic (anul 2016) - 244,7 ha. Se află în trupul de pădure „Naslavcea”. Pentru prima dată ecosistemului silvic „La 33 de Vaduri” a fost menţionat de Iu. Kravciuk, V. Verina, I. Suhov (1976) în lucrarea «Zapovedniki i pameatniki prirodî Moldavii». Autorii menţionează prezenţa pădurilor naturale de stejar pedunculat cu carpen şi jugastru pe soluri podzolite şi substrat al carbonaţilor din sarmaţianul inferior, iar în malurile abrupte a râuleţului Naslavcea sunt prezente dezgoliri şi expunerea rocilor din torton şi cretaceu. Se menţionează prezenţa speciei rare Lembotropis nigricans (L.) Griseb. (= Citisus nigricans L.), iar în pădurea din lunca râului Naslavcea prezenţa unui 
stejar secular cu diametrul de $86 \mathrm{~cm}$ şi înălţimea de $18 \mathrm{~m}$.

În rezervaţia peisajeră „La 33 de Vaduri” sunt 126,7 ha (51,8 \%) arborete de stejar, 1,7 ha $(0,7 \%)$ sălcişuri, 94,9 ha $(38,7 \%)$ păduri artificiale. Terenurile fără păduri - 21,4 ha $(8,7 \%)$ sunt constituite din vegetaţie de pajişti de luncă în valea râului Naslavcea, iar pe povârnişuri - pajişti xerice din cl. Festuco-Brometea.

În habitatul silvic sunt prezente arborete de tipul Carpineto-Quercetum (roboris) cu următoarea compoziție: Quercus robur L., Q. petraea Liebl., Carpinus betulus L., Cerasus avium (L.) Moench, Tilia cordata Mill., Pyrus pyraster (L.) Burgsd., Acer campestre L., A. platanoides L., A. tataricum L., Ulmus campestris L. , Salix alba L., Malus sylvestris Mill., precum şi specii alogene: Robinia pseudacacia L., Acer negundo L., Pynus sylvestris L., P. nigra Arnold, Juglans regia L., arbuşti: Euonymus europaea L., E. verrucosa Scop., Lonicera xylosteum L., Sambucus nigra L., Cornus mas L., Rosa sp., Ligustrum vulgare L., Crataegus monogyna Jacq., Viburnum lantana L., Swida sanguinea (L.) Opiz, Crataegus curvisepala Lindm., Corylus avellana L., Viburnum opulus L., Rubus caesius L., Staphylea pinnata L., Cerasus vulgaris Mill., Prunus spinosa L., Hedera helix L., ierburi: Carex pilosa Scop., C. brevicollis DC., Aegopodium podagraria L., Poa nemoralis L., Pulmonaria obscura Dum., Glechoma hirsuta Waldst. et Kit., Asarum europaeum L., Stellaria holostea L., Dryopteris filix-mas (L.) Schott. Nu a fost identificată prezenţa speciei rare Lembotropis nigricans (L.) Griseb. menţionată de Iu. Kravciuk ș. a. (1976) - component al pajiştilor xerice, suprafețele cărora au fost plantate cu specii de arbori alogeni - salcâm, pin, molid, mesteacăn.

În rezervaţia peisajeră „La 33 de Vaduri” s-au evidenţiat 13 specii de plante incluse în Lista speciilor de plante rare din Republica Moldova (1998) - Epipactis helleborine (L.) Crantz., Lathyrus venetus (Mill.) Wohlf, Viburnum opulus L., Staphylea pinnata L., Vinca minor L., Aconitum anthora L., Lonicera xylosteum L., Adonis vernalis L., Majanthemus bifolium (L.) F. W. Schmidt, Dryopteris filix-mas (L.) Schort, Hepatica nobilis J. Gay, Padus avium Mill., Galanthus nivalis L., iar ultimile 5 specii sunt incluse în Cartea Roşie a R. Moldova.

Rezervaţia peisajeră „La 33 de Vaduri” este un obiect ecologic valoros, care necesită o amenajare peisajeră specifică cu implicarea nu numai a silvicultorilor, dar şi a cercetărilor fitocenologi, ecologişti spre prosperarea tuturor componenților naturali din ecosistemul silvic.

\section{BIBLIOGRAFIE}

1. Кравчук Ю. П., Верина В. Н., Сухов И. М., 1976 Заповедники и памятники природы Молдавии. Кишинев: Штиинца. 312 с.

2. ICAS Chişinău, 2016. Amenajamentul silvic OS Ocniţa, ÎS Edineţ.

3. Cartea Roşie a Republicii Moldova. Ed. a 3-a. Chişinău: Ştiinţa. 2015. 492 p. 